\title{
Of Gifts and Commodities
}

\author{
Spending on the Dead While Providing for the Living
}

Economists often talk about "the economy" in the singular. The economy is where goods and services are exchanged for cash. Since cash is countable, by examining the economy as a single field, economists can mathematically analyze universal economic rules. Anthropologists, however, tend to see a diverse array of partially separable economic processes instead of a singular economy. They are interested not only in mathematical flows of money, but also in the moral rules and social logics that inform patterns of exchange. Some productive activities, like housework and childcare, may not involve the exchange of cash at all, but do involve strong moral norms as well as value creating forms of labor. In the case of the funeral of Mr. Wang, we saw how his younger daughter provided a great deal of care work in the hospital for free, partially because she saw this work as her moral duty as a daughter. But even if we restrict ourselves to discussing activities where cash is exchanged, we can observe differing social, moral, or legal frameworks that structure the ways in which exchange takes place. Giving cash as a gift, as occurred when the households of Mr. Wang's nieces and nephews visited the Wang family home altar before Mr. Wang's funeral, involves different expectations than paying cash to a funeral home for the services it provides. Giving cash as a gift recreates kinship relationships between households of givers and receivers. Paying cash to the funeral home, in contrast, does not establish a kin-like relation between the funeral home and the family holding the funeral. As they involve different types of social relationships, the two types of cash exchange also involve different sets of moral expectations.

My point here is not simply that the economists are wrong and the anthropologists are right. The whole point of money is to transcend difference. Money received as a gift can be turned around and spent at a funeral home. But even though money can be used to do almost anything, people tend to use money in 
specific ways, to categorize money according to specific purposes, and then to attach different moral and social rules to differing categories of money. There can be rent money, drinking money, lottery money, gift money, money for the grandchildren etc. This is as true of modern money as it was true of the so-called traditional, special-purpose currencies, like cowrie shells in New Guinea. ${ }^{1}$ It is also as true in the formal economic realms of state taxation and business accountancy as it is in the informal economies of households or street peddlers. But alongside the relative universality of categorizing money, there usually exist forms of inventive morality, novel rule interpretation, or creative accounting that allow money of one type to be used as if it were money of another type. A strong analysis of the economic activities, moralities, and processes involved in funerals should depict both the different moral shapes this economic activity takes and the ways in which actors switch from one type of economic morality to another.

Distinctions among different forms of exchanging money often involve different ways of defining the social relationships between the people involved in the exchange. In the last chapter, we saw how patterns of kinship and modes of interacting with strangers have evolved as China urbanizes. This chapter carries this theme forward from an economic perspective. Funerary economic transactions influence four types of socioeconomic relationships. These are those within the household (defined here as a group who pool economic resources and share a common budget), the extended family (potentially including distant relatives, friends, and fictive kin relations), strangers who are to remain strangers, and the overarching political nation, that is, those who participate in markets regulated by the People's Republic of China.

Different forms of social relationships can be seen as involving different forms of capital. In pooling a budget, households are held together by economic capital-money. Extended families are held together by social capital, a form of trust extant in long-term social relations. The larger political regime is held together by political capital, that is, loyalty to the Chinese Communist Party. Large firms, like the cemeteries examined in chapter 3 , secure favorable conditions for conducting business by bolstering the legitimacy of Party rule. People who want to keep strangers at arm's length, to make them remain strangers, strategically avoid sharing any form of capital. In manipulating their social relationships and forms of capital, economic actors sometimes attempt to transform one form of capital into another, thus blurring the boundaries among different types of economic morality.

The diversity and transformability of economic moralities in China today is driven in part by the legal ambiguity under which much economic activity takes place. Three types of legal ambiguity influence funerary economic activity: the ambiguity of ritual activities involving gods, ghosts, ancestors, or other "religious" or "superstitious" actors that could be labeled as illegal superstitions; the ambiguity of gifts given between households when the household receiving the gift could 
include a cadre or a business leader and the gift could be labeled as a bribe; and the ambiguity of small-scale businesses that neither obtain state licenses nor pay taxes. I begin by briefly reviewing patterns of urban economic development during the post-Mao era. I focus on the types of economic shifts that have affected most of China's larger urban areas. Then, I examine five forms of economic morality and exchange involved in funerals during the period of my research. This material constitutes the bulk of the chapter and derives mostly from my research in Nanjing, where I was able to collect relatively detailed economic data. Finally, I analyze the failed attempt of a large insurance firm to disrupt the entire funerary industry. Despite the failure of this particular attempt, the strategies and thought processes of the insurance company reveal much about patterns of economic exchange in contemporary urban China.

\section{FROM PLAN AND WORK UNIT TO HOUSEHOLD REGISTRATION AND MARKET}

During the Maoist era planning dominated the Chinese economy. Urban residents worked in work units. Housing was provided either through work units or the municipal government. Migration from rural areas was strictly regulated. Cities had many factories, and factory workers were considered both the largest and most important sector of urban employees. Almost all consumption took place in state-run stores. Though service in such stores could be poor, and often depended upon establishing some sort of relationship with a store clerk, the only alternative was to purchase goods illegally on the black market. Income levels were low, but alongside the poverty was a relatively high level of economic equality, at least among those who were official urban residents of the same municipality.

During the post-Mao era, economic reforms have come one on top of another. While a detailed history of these reforms is beyond the scope of this study, exploring a few of the major trends provides a context for the discussion of funerary economic exchanges. As described in the last chapter, the role of work units has declined. The majority of young and middle-aged people no longer work for a work unit that provides all-inclusive lifelong benefits. To lessen urban pollution, factories have been pushed out of large city centers; more importantly, the biggest cities in China envision themselves as entirely post-industrial, middle-class spaces, rather than industrial, working-class ones. Overall, economic growth has been strong and rapid, with the result of increasing spending in most sectors of the economy, including funerals. As people become wealthier, they rely more and more on cash to purchase goods and services from strangers rather making do with what they have, constantly repairing old items themselves, or undertaking almost all of their own cooking, cleaning, sewing, and shopping. Commercial enterprises compete to provide good service to customers. Increasing wealth has 
also allowed cities to grow in size, expanding their borders and developing their infrastructure; almost all large Chinese cities now have extensive subway systems. Housing has been privatized and the price for apartments has skyrocketed, especially in the largest cities in the eastern part of the country. As municipal governments rely on profits from selling and rezoning land, they have developed interests in both continuing urban expansion and maintaining high real estate prices. Many young people are unable to afford apartments and must rely on their parents for living space. Inequality has increased, with the emergence of both impoverished urban residents and migrant workers from the countryside, who undertake most of the dangerous, despised, and most poorly paid occupational niches. The experience of rapid increases in living standards in a context of growing inequality and expensive housing makes many fear the possibility of being left behind. Because many urbanites see housing as a necessary precondition for marriage and forming an independent household, fears of being left behind economically and fears of not being able to continue the family line intertwine.

As migrant workers move to the city from the countryside, they have come to dominate certain sectors of the economy, including funerary services. Though some manage to get their household registrations transferred to the cities where they live, many do not. One result of this lack of registration is that many migrant workers either choose or are forced to spend their old age and then die in the place where they come from. All of the one-stop dragon entrepreneurs I asked said that they only did funerals for people who had either a local urban household registrations or a rural household registration in one of the villages at the edge of the urban core.

Finally, social media and new communications technologies have rapidly influenced the way urban Chinese, and almost everyone else, lives their lives. Information and services that used to require travel to a physical store are now often accessed through social media. The last section of this chapter explores how the digital revolution might affect funerary economies.

\section{THE FIVE ECONOMIES OF URBAN FUNERALS}

As Caroline Schuster (2016) points out in her analysis of death ritual and credit in Paraguay, funerals are moments for a settling of accounts for the dead and an opening of new accounts for the living. In contemporary urban China, this settling and opening of accounts takes place across (at least) five different forms of economic interaction: the inter-household gift economy, the intra-familial inheritance economy, the state redistributive economy, the small-scale informal market economy, and the large-scale formal market economy. Because funerals are complex economic affairs, I illustrate these five modes of exchange with data from different funerals. I could not simultaneously follow all five processes in a single case. While the five modes of economic exchange proceed under differing moral 
codes, the codes are all shaped by the forms of socioeconomic grouping described above: the household, the extended family, and the political nation.

\section{Inter-Household Gift Economy}

Funerals across China involve gift-giving. As we saw in the funeral of Mr. Wang, in the city of Nanjing, relatives of the deceased often give cash gifts and flower wreaths when they come to visit the home altar of the deceased during the period before the farewell meeting. The hosts of the funeral (typically the children of the deceased) keep a gift register in which the names of all those giving gifts and the amount they give is recorded. Those who give gifts will usually be invited to a banquet after the funeral and be given a small return gift at the banquet.

While I never saw the gift register for Mr. Wang's funeral, another Nanjing household showed me the gift register from their eighty-year-old father's funeral in 2015. At that funeral, thirty-five people gave slightly more than 25,000 yuan in gift money. The father had two brothers and two sisters who had a total of seven children. The brothers and sisters themselves each lived with one of their children, so there were seven gift-giving households from the father's side of the family, each of whom gave between 1,000 and 2,000 yuan. The surviving mother had one sister who was still alive and five nieces and nephews, making a total of five more households who also gave between 1,000 and 2,00o yuan each. The deceased had three children - two sons and a daughter-and a total of twenty additional households, including relatives of the children's spouses as well as a few close friends, gave between 100 and 500 yuan each. Finally, three neighbors who had been friends of the father gave 100-200 yuan each. The total amount given at this funeral was slightly more than what was given at Mr. Wang's funeral, but similar to most other middle-class urban families I heard about.

This amount would have been much larger at the funeral of an important government official, at least before the Xi Jinping-instituted crackdown on giving gifts to cadres at the funerals of their parents. Gift-giving relationships imply an indebtedness that can encourage corruption, but it is not only powerful cadres and anticorruption agencies who worry about the implications of indebtedness. The household of the eighty-year-old father also refused one gift. An associate of one of this household's sons-in-law attempted to give the deceased's wife a gift of 3,000 yuan (larger than any other) three days after the funeral. He was not particularly close to the family and had not been invited to the funeral, but wanted to deepen his business relationship with the son-in-law. The mother declined the gift, saying that the funeral had already passed. She told me that the families were not close enough to know of each other's funerals and that the morality of exchange demanded that they would have had to return a larger gift in the future, but they would not know when to do so. Without the ability to reciprocate, the gift would become a burden, an unrepayable debt, hanging over the head of the son-in-law. This example demonstrates that the legal ambiguity in drawing the line between gifts and bribes 
reflects a serious moral problem: how to separate economic relations based on moral ideologies of fairness that require all to be treated equally with social relationships in which economic obligations for some people are greater than those for others.

The logic of inter-household giving at urban funerals closely resembles that already depicted in the literature on gift-giving in China, ${ }^{2}$ but a few points deserve reiterating. First, as the mother's comment indicates, gift-giving involves a logic of continual inflation. If one of the households that gave a gift at this funeral were to hold a funeral in the future, then the mother's household should give an amount larger than the amount they received at this funeral. To return the same amount would cancel the indebtedness between the households and thus end the relationship. Second, none of the households who might inherit something from the deceased (the mother, the three children, and various grandchildren) could give a gift at this funeral. They were the direct mourners and thus constituted the group of gift-receivers at this funeral. Third, the practice of giving gifts draws economic boundaries around households. Gifts are understood as coming from a household. In no case do different members of a household give two separate gifts. Though the receiving unit could be seen as comprising several households, the key members of those households were originally all members of the deceased's household. That is why they could inherit. Households form and break up over time, but while they are intact they have strong economic boundaries. Because funerals mark a time for potential shifts in household structure, they become important moments for recreating kinship bonds among households. New accounts of indebtedness and relatedness are created.

Three forms of economic grouping are visible in these transactions. First are the households themselves, defined as gift-giving and gift-receiving units. Second is that of the extended family defined by the networks of debts recorded in the gift register. Third are those non-family members who are excluded from the bonds of social capital shared by family members. The example of the refused gift shows how the morality of maintaining relationships of indebtedness through gift exchange can be manipulated to influence wider forms of economic exchange. The mother feared that the social capital gained by the man who wanted to give 3,00o yuan would one day require her son-in-law to give the man a form of economic benefit that was even more valuable. The man was forced to remain in the category of non-kin.

Tensions over defining the boundaries of extended families go to the heart of the moral problems of economic exchange in urbanizing China, and perhaps throughout the contemporary world. As urbanization increases the space for strangers in our lives, fairness, or treating everyone the same, becomes the predominant moral guideline for economic interaction. But logics of family or community require treating in-group members with higher levels of generosity and compassion, and the lines distinguishing in-group and out-group members 
become starker. Friends occupy a potentially uncomfortable moral place in the logics of exchange, destabilizing the distinction between kin and strangers. Governmental and corporate agencies, as well as familial elders, all have a stake in defining who does or does not belong to the extended family. Funerals are one of many moments when such boundaries become explicit.

\section{Intra-Familial Inheritance}

As we saw in the case of Mr. Wang, the death of a parent often marks the start of struggles over inheritance. In urban China during the period of my research, several factors exacerbated such tensions. First, the generation of people passing away in urban areas typically had their children before the birth planning policy was implemented in 1979; they often have three or more children. Second, this generation worked in an era when work-unit employment was the norm. Most, even if they were factory workers, own apartments and receive pensions and, thus, have significant assets to leave to their children. Third, the 1990s, 2000s, and $2010 \mathrm{~s}$ have been periods of rapid increase in urban real estate values. The value of apartments has increased much more rapidly than incomes, and even the small dingy apartments of former factory workers can be worth a fortune, especially in relation to the income levels of their children. For many urban families, the value of the property to be inherited is many times larger than the annual incomes of the heirs. In addition, many elderly people in China do not want to think about the fact that their children may be preparing to fight over their inheritance. They avoid the issue by not making out a will. Finally, the moral logics around inheritance (but perhaps not so much the legal logics in this case) can be contradictory and ambiguous. Many sons and daughters-in-law argue for a patrilineal logic of inheritance. Daughters tend to suggest that inheritances should be split evenly among all the children of the deceased, and the law generally agrees with them. Finally, many people feel that inheritance should depend on the quality of the relationship between parents and their children and the amount of physical and emotional care and financial support a particular child gives to the parents in their old age. The courts also consider this support in their rulings. ${ }^{3}$

During my research, I learned of many conflicts that ended up in the courts. A man who ran a small business arranging funerals in Nanjing told me:

It seems that more than half of the funerals I do involve siblings quarrelling over the inheritance. They will try to keep the hostilities under control for the three days between the death and the funeral itself, as quarreling at the funeral is inauspicious. But some cannot even keep their tempers in check for that long. I know many families in which the siblings no longer speak to one another.

In one case, a long-retired factory-working couple passed away together in an auto accident. They owned a ninety-square-meter apartment in a former workunit housing complex that was centrally located near downtown Nanjing, close 
to parks and a subway stop. Though not fancy, the apartment was worth over 2 million yuan. In addition, the family received a pension payout of over 200,000 yuan. The couple had two sons and a daughter. All were married; the sons had one child each but the daughter was childless. The mother had been ill before the auto accident and the daughter had provided most of the care. None of the children had attended university and all worked service-sector jobs, earning between 2,00o and 4,000 yuan per month. The value of the property to be inherited was more than forty times greater than the annual incomes of the children. The sons claimed that the daughter should not receive any inheritance, as she was childless while they were continuing the family line. The daughter claimed a share because she had spent considerable time caring for her mother. The case went to court, which ruled that the inheritance should be split evenly. The sons were appealing the case when I finished my research, and the siblings only communicated through their lawyers.

In this case, differing moral logics of inheritance conflicted. The logics of continuing the family line (which are often patrilineal, although not in this case as the daughter was childless) conflict with logics of reciprocity which dictate that those giving care to the elderly should receive an inheritance. In the case of the funeral of Mr. Wang, we saw how the son and daughter-in-law invoked patrilineal logics. They insisted that since only the patrilineal grandson of Mr. Wang would have the surname Wang, all of Mr. Wang's wealth should pass to him. They raised another point as well. In contemporary urban marriage markets, the marriageability of a young man is very often tied to his ability to provide an urban apartment for the new couple. Since women do not face such expectations, in a family with many grandchildren, grandsons should have preference over granddaughters and paternal grandsons absolutely must have access to an apartment (or the wealth to purchase one) if there is any hope for continuing the family line. I often heard such logics spoken when asking about issues of inheritance.

In rural China, both today and in the past, formal practices of dividing the household (分家) usually kept such conflicts under control. ${ }^{4}$ But in contemporary urban China, traditional ways of dividing the household are largely lost and conflicts often end up in the courts. The existence of these disputes shows the importance of economic capital in the constitution and reproduction of households. The fact that strict patrilineal logics of inheritance are being successfully challenged by daughters on the basis of their care work (where such challenges would not have been entertained in a relatively recent past) is evidence of the changing moral and economic structures of the basic unit in Chinese society (the household). Nevertheless, the claims of sons are not, either socio-morally or legally, dismissed outright; patriarchal assumptions persist.

Finally, note the differing economic moralities of the inheritance and the gift economies. The inheritance economy is primarily about forming households, and it is in this context that patrilineal arguments hold their greatest moral sway. In the inter-household, intra-familial gift economy, relatedness defined in 
a patrilineal fashion matters little. Households strive to maintain connectedness with other related households regardless of whether those relations are through men or through women. In a context of disintegrating urban communities, relatives often constitute the only community one can sustain. In addition, the birth control policy has yielded many households with single daughters, and the parents of such households are especially reluctant to give up their connections to other households.

\section{The State Redistributive Economy}

As the pension payout to Mr. Wang and the above case demonstrate, the state, or, more precisely, municipal governments play a heavy role in governing death. In Nanjing the economic governance of death flows through two channels. First the Civil Affairs Bureau (民政局) regulates the state-run funeral home/crematoriums as well as the urban graveyards. It forces these institutions to keep prices artificially low for their most basic services (while allowing them to profit from everything else), regulates the types of rituals that can proceed at these places (recently banning firecrackers used to scare away ghosts, for example), and provides free basic funeral services for impoverished households without pensions. Second, work units, or the government units that have taken over their pension burdens if they no longer exist, provide pension payouts and additional services to the families of dead people who originally worked at their unit. Under 2016 Nanjing municipality regulations, upon the death of a pensioner, the families of the deceased receive a payout equivalent to twenty-four months of pension payment. Pensions vary greatly in Nanjing - as low as 1000 yuan per month, or higher than 10,000 yuan for high ranking cadres. Because pensions have gone up regularly over the years, people who retired long ago often receive higher pensions than those who retired recently. In 2015, factory workers who retired at the age of fifty in the 1980s often received pensions of 3,000-4,000 yuan per month. The politics of pension reform is a fraught area, but most cities in China pay out retirees for life at state-regulated levels rather than giving workers Individual Retirement Accounts. Pension levels have been a cause of protests in many cities, and relatively high pensions are often seen as a way of maintaining social stability (维稳). Some people suspect that pension payouts are a strategy for buying political peace (see Hurst and O'Brien 2002). They encourage people to report the deaths of their aged parents-in the past there were rumors of people continuing to collect pensions while storing their dead parents in refrigerated caskets - and give families an immediate payout at a time when they face funeral expenses and may be feeling strong emotions that could turn against the state. In addition to the pension payout, certain work units provide other benefits at the time of death, such as transportation to the funeral, small cash gifts to the family when a representative is sent to visit the home altar, and help with arranging the funeral. The families of high ranking cadres receive even more types of benefits. As Martin Whyte (1988) details, during the Maoist 
era, most urban funerals were arranged by work units. In contemporary urban China, the role of the work unit has diminished for most people, but is still crucial for state employees.

Two forms of moral logic inform the state redistributive economy in relation to death. First, as with all forms of state benefit, bureaucratic logic demands the pigeonholing of people into different categories to determine what sorts of benefits they should receive. Migrant workers in Nanjing, for example, are not eligible for any sort of death benefit. While the construction of the pigeonholes may be unfair, bureaucratic morality requires that the pigeonholing itself be done fairly and accurately. Such an explicit logic of fairness distinguishes state-led economic activities from the logics of inter-household gift exchange. But a second logic of reciprocity also emerges: families should express gratitude towards the state and its bureaucratic workers for the payouts by not using funerals as an excuse for an outpouring of anti-state emotion. In this sense, the pension payout is a way for the state to transform economic capital into political capital and reproduce the loyalties that link households to wider structures across society. Access to state payouts also helps define those who receive the payouts as citizens of a particular municipal area in China, and, by extension, as citizens of the People's Republic of China. In this sense, political loyalty at death is not only a matter for large companies, but also for urban households with local household registrations.

\section{Small-Scale Informal Economies}

Funerals can involve many small-scale businesses. There are vendors who sell flowers, spirit money, and other items for burning from carts on the street in front of cemeteries and funeral parlors; religious practitioners who offer services such as chanting sutras for the dead; musicians who play dirges in funeral processions; and, most importantly, one-stop dragon entrepreneurs like Mr. Chen. Almost every community in Nanjing has a one-stop dragon entrepreneur. Other one-stop dragons open small shopfronts near major hospitals. Most families will employ such a person when faced with death. In Nanjing, these businesses typically price three days of service at about 1,00o yuan, which is well under cost. But they require the customers to purchase cinerary caskets, longevity clothes and sometimes packets of return gifts from them, and make their profit selling these items.

While some such businesses have shopfronts which display these items, others just have a phone number and business cards. Many do not bother obtaining business licenses, and even those with licenses and shopfronts only pay taxes on those rare transactions when a customer demands a receipt. Though the busiest of these businesses can do hundreds of funerals a year, and often require two people for a single funeral, they rarely formally employ anyone. Everyone who works at such an establishment does so as an independent contractor and has no insurance or pension payments made by the business. ${ }^{5}$ The businesses also pay kickbacks to those who refer customers (often nurses at the hospitals), and sometimes 
receive kickbacks if they direct customers to particular graveyards. Most of their informal employees are relatives and all transactions are in cash. Of the twelve such entrepreneurs I interviewed, all came from rural areas near the cities where they worked.

In addition to the funeral of Mr. Wang, Mr. Chen shared with me the financial details of another funeral. In this case, I was at his shop one afternoon when a woman approached. Her mother had just passed away one Tuesday in the early afternoon. She had learned about the business from the helper who had provided night care for her mother. After a brief negotiation the woman agreed to pay 900 yuan for three days of service, purchase a 1,000 yuan longevity clothes set, spend 800 yuan for twenty return gift packets, and buy a cinerary casket (which ranged from 1,500 yuan to 10,000 yuan), though she wanted to consult with her family about which one to buy. Mr. Chen then took his son-in-law with him to accompany the woman to her home. After they arrived in the woman's apartment, they met the woman's husband and child. Mr. Chen then went with the woman's husband to drive to various offices to make arrangements and obtain certificates. He accompanied the husband for two hours that afternoon and six hours on the following day. After some direction from the entrepreneur, the woman made a list of people to be notified and began contacting them. Mr. Chen's son-in-law stayed at the home to set up the home altar and to write calligraphy for visitors who came with flower wreaths. The son-in-law spent six hours in the home on Tuesday and twelve hours on Wednesday. The farewell ceremony, cremation, burial and banquet took place on Thursday (the third day) and Mr. Chen accompanied the family for the entire morning (from 5 a.m. until the banquet at noon). The son-in-law convinced the family to purchase a 2,800-yuan cinerary casket. In all, the family paid the entrepreneur 5,500 yuan in cash. The wholesale cost of the items sold was about 1,200 yuan. Mr. Chen gave a 500-yuan kickback to the referring nurse (double the usual amount because this case was the first referral for this nurse) and 1,000 yuan to his son-in-law (500 of which was a commission on the cinerary casket). He also drove his own car to some of the offices, paid for some small items used in setting up the home altar, and had expenses related to renting his shopfront, but he still estimated that he made close to 2,000 yuan on the funeral.

Two moral logics inform the process. The first is that of immediate cash payment for all services, with a short time-frame around each transaction. Opposite to the logic of the gift economy, the norm here involves clearing all debts as soon as possible. There is no attempt to create social capital by maintaining relations of indebtedness. Trust is possible because payments come quickly. The second is one of kinship. Mr. Chen hired his son-in-law and often used idioms of kinship, or at least friendship, when addressing the people with whom he did business. A basic paradox of relatedness emerges here. On the one hand, part of the spirit of the economic morality involved in these transactions was that of family. Households gave and received payments in economic transactions, while forms of fictive 
and real extended family relations were invoked to establish the trust or social capital that enabled economic transactions to take place with minimal reference to the state. Though Mr. Chen's relationship to his son-in-law was clearly ongoing, the use of fictive kin terms among the other actors allowed only for transactions in which service was performed on one day and payment was received a day or two later. Formal, state-related economic processes were avoided at every turn, in part because many aspects of Mr. Chen's business were technically illegal. He did business in cash only and did not pay taxes. Businesses like his thrive in a legally ambiguous environment in which the municipal government desires a dynamic economy and high levels of employment, but also wants all businesses to register.

On the other hand, the quick cash payouts make it possible for the relationships involved in these economic transactions to be severed at a moment's notice. As noted in the previous chapter, workers in the funerary sector, including Mr. Chen, are often stigmatized. Many of their customers do not want to have any ongoing relationship to them. For the customers, the use of idioms of friendship or distant kinship are at best necessary fictions to enable the transaction to proceed. They imply nothing about their relationship to the entrepreneur.

\section{Formal State-Regulated Business Economies}

There are three types of formal enterprises involved in the funeral industry. The first are the state-run funeral home/crematoriums, usually run by the city's Civil Affairs Bureau. Second are the cemeteries, more often privatized but always run by large corporations approved by the Bureau. Third are one or two large insurance companies who are attempting to establish nationwide markets in funerary insurance and pre-paid funerals. All of these types of businesses either formally hire their employees or go through officially regulated employment agencies which pay the insurance fees of their employees. Though some of the employees are given incentives to sell the most expensive of services, most of the employees' income comes from their regular salary. The prices these companies charge are fixed and publically displayed. They issue receipts after customers make payments and pay tax regularly, though they also occasionally pay cash kickbacks to one-stop dragon entrepreneurs who steer business to them.

Though these enterprises operate in the formal, legal, state-regulated economy, contradictions between their state affiliation and their customer orientation shape their economic interactions. The graveyards and the insurance agencies require long-term economic trust from their customers, who buy graves for twenty to thirty year periods (with options to extend) and can pay for pre-paid funerals or funerary insurance decades before the funeral is carried out. In presenting themselves to their customers, these companies emphasize their size and state affiliations to suggest that they will be around for the long haul. The funeral home /crematoriums are run by the state, and many of their prices and services are directly shaped by state regulations. But because funerary ritual often involves activities 
that could be construed as "religious" or "superstitious," all of these companies must negotiate the line between shaping funerals according to state aesthetics and shaping funerals according to customer desire. In addition, because the state subsidizes cremations and basic services for the poor, the funeral homes must sharply distinguish pricing strategies for basic and optional services. For example, in Nanjing in 2016, the price to rent a small room to hold a farewell meeting was only 100 yuan/hour. But the price to decorate the room appropriately with flowers started at 3,000 yuan and could go as high as 50,000 yuan.

The contradictions regarding "superstitious" activities are even starker. Funeral homes have rules about the types of ritual, religious, and "superstitious" activities they will allow, drawing lines that can seem arbitrary. Graveyards commonly provide burial services during which the master of ceremonies may refer to various ghosts, gods, and ancestors, as well as Buddhist notions of heaven and hell, and even ideas from Western astrology. The master of ceremonies may also make reference to practices that are said to bring good luck to the deceased's decedents. Such references were visible in the burial ceremony of Mr. Wang as well as at several other burial ceremonies I witnessed. Cemeteries also can employ geomancy masters to help people choose gravesites. But they still ban certain activities when required, such as setting off firecrackers (used to scare away ghosts) or burning spirit money. In addition, as discussed in chapter 3, some graveyards go to great length to bury Party and national martyrs, reserving special sections of their graveyards for them, devising elaborate memorials, and opening the cemeteries to the public to offer lessons on the glorious history of the Party to tourists and visiting groups of schoolchildren. Such actions both curry favor with Party officials and demonstrate their relationships to the Party-state to customers. Some customers will pay a premium to be buried (or bury loved ones) at a cemetery that is also home to Party heroes.

In short, these formal enterprises blend two political-economic moral logics. For their economic stakeholders (stock owners for the private corporations and those employees who share in the profits for the state-run funeral homes), they must do whatever it takes to make a profit_charging as high a price as the market will bear and providing whatever services customers demand. But they must also politically support the local branch of the Communist Party, regularly performing their loyalty and enacting any policies the government demands. At times these enterprises find ways of seamlessly blending the two missions, as when the Fu Shou Yuan or the Garden of Merit build memorials for Party designated martyrs, whose presence then attracts high-end customers to purchase plots. But in other instances the two imperatives contradict one another and compromises are reached. The relationship between the two types of logic is often seen as a type of reciprocity: the companies perform loyalty to the Party and the Party gives the companies the regulatory space to be profitable. As many scholars have noted, large capitalists in China almost always forge alliances with state cadres in the 
districts where they operate (Dickson 2008; K. Tsai 2007). In these examples, the social entity of the Party (with its claims to represent the nation as a whole) and the political capital of those who can build a relationship with the Party-state loom large. But the moral logics of these processes differ from those of the technically illegal small-scale businesses described in the last section.

\section{DISRUPTION AND EMERGENT DIGITAL ECONOMIES}

The five types of economy described above provide a snapshot of monetary interactions at funerals during the period of my research. The general economic shifts described at the beginning of the chapter provide some historical context for those inclined to imagine how aspects of this monetary economy may have waxed and waned over the proceeding decades. In this section I examine a case of an attempt to disrupt the entire funerary industry. Such an attempt turns our attention to the future of funerary economies.

"We are going to do to the funerary business what Uber did to the taxi business," declared an enthusiastic recruit at what I took to be a funeral business office in Beijing in September 2015. The recruit invited me into his office when he saw me speaking to a neighboring funerary services shop and showed me a website that his company, Love Convergence (a pseudonym), was developing to enable browsers to scroll through a menu of elements to include in a contemporary urban funeral. The recruit explained that until his company came along, people wanting to arrange funerals did not understand what to do with a dead relative and were at the mercy of unscrupulous funerary parlor workers and one-stop dragon entrepreneurs. By developing a website, Love Convergence would modernize an ancient and corrupt industry and bring transparency to what had been an opaque process. "But how can your company provide this range of services across the entire country?", I asked. "We are not a funeral business, ourselves," he answered, "but a life insurance company. We want to be the first company to open the funerary insurance market in China."

Anthropological discussions of the insurance industry have consistently argued that cultural context has a powerful influence on the way insurance markets develop in a given country. Viviana Zelizer (1979) shows how insurance companies in the United States had to overcome moral reservations about putting a price on life by inventing moral discourses about responsibilities towards children and dependents in the case of death. In China, Cheris Chan (2012) found that life insurance companies had to overcome taboos about talking about death to establish their market. They did so by promoting insurance as a type of investment rather than as a form of protection against an unfortunate early demise. While Chan's and Zelizer's insights illuminate Love Convergence's plans, I later came to question whether their plans had anything to do with "insurance" at all. At the heart of the company's business model was a scheme for raising capital, rather 
than a plan for sharing risks (as insurance is often depicted). The scheme itself evolved rapidly, as the company adjusted its services in response to problems that arose while setting up the business.

\section{The Rapid Evolution of an Insurance Vision}

Love Convergence was founded by Longevity Life Insurance (also a pseudonym), one of the largest life insurance companies in China. In 2013 the company founded a subsidiary to service China's elderly. The subsidiary provides four types of service: retirement homes and communities in China's wealthiest cities; medical services for those living in its communities; financial and legal services for older people with money to invest and give to heirs; and funerary businesses, with cemeteries and the web platform described above. Love Convergence was a subsidiary of this subsidiary. With three hundred employees in five cities across China, it was merely the tip of the iceberg of Longevity Life (which employs millions of people across hundreds of Chinese locales).

Love Convergence evolved rapidly after its establishment in 2015. The website I was shown in September 2015 quickly lost its specific menu for services. By October 2016, the website instead explained how the contract for "funeral insurance" works. A person may buy the policy for oneself or a close relative, most typically an elderly parent. The website is full of images suggesting a caring, filial relationship between an elderly parent and a middle-aged son or daughter. The purchaser specifies whose funeral the contract is for and who will be the "beneficiary," that is, the person who will be in charge of the funeral once the elderly person has passed away. The purchaser specifies the exact level of service she desires for the funeral and pays the full price for this funeral in advance. Upon the death of the insured person, the beneficiary has the option of either carrying out the funeral as specified in the plan or getting the money back with 3 percent annual interest added. In the USA or Australia, such a contract would be called a type of prepaid funeral, rather than funeral insurance. When I asked why Love Convergence markets these policies as a type of insurance, I was told that the contracts insured against both the inflation that might occur in the price of the funeral between the time the policy was drawn and the time the policy was carried out, and also against the fact that someone might carry out the funeral in a manner that the purchaser or the insured person would find distasteful. While I would agree that the policy does insure against extreme inflation, the latter claim seems slightly exaggerated. The beneficiary could still take the money back with 3 percent annual interest and then carry out the ritual in a manner that did not reflect the original contract, though having everything spelled out in a contract could serve as an explicit guide for those designing a funeral.

Further interviews with mid-level company managers I conducted in 2016 suggest that the company had to abandon the menu for services they had originally showed me because the typical services desired and prices charged varied from 
city to city in China, making a uniform website impossible. The price of a funeral in China's wealthiest cities (Beijing, Shanghai and Guangzhou) average about 20 percent higher than in the other provincial capitals and 50 percent higher than in many smaller cities. As of October 2016, the website urged visitors to contact one of their service "angels" any time, twenty-four hours a day, though telephone or the website. The angels can explain the options available and their cost and even come to your home to help you plan the funeral and choose a gravesite, should you desire.

Also in 2016, a manager in Love Convergence's Shanghai office explained that they had standardized their funerals into two packages-a basic-level funeral for 18,00o yuan and a high-level funeral for 35,000. To hedge against inflation, these prices were about 20 percent higher than current costs. Standardizing the insurance packages into two levels, the manager explained, was a reaction to their customers: "Few people have very specific ideas for their own funerals. What customers want is either a good basic funeral which will not stigmatize them as poor or stingy in the eyes of their friends and families, or a high-level funeral which will distinguish them as being either wealthy or filial." But beyond the basic expression of either standard but respectable or distinguished and special, he added, most customers desired expert advice about the specific items to be included to mark these particular levels of ritual. ${ }^{6}$

During their first ten months of business, Love Convergence sold roughly one hundred such policies in Shanghai. Given the population of Shanghai (over 20 million), this number of policies did not even amount to 0.01 percent of the city's elderly population. The customers were primarily people who worried about not having someone to arrange their funeral. These included the children of elderly Shanghainese who lived abroad, who would attend the funeral but feared that rushing home to attend it would be difficult enough and wanted all of the arrangements in place. Alternatively, the policies were purchased by elderly Shanghainese who had no children and who did not have a living spouse.

During the short period between 2015 and 2016, the entire depiction of insurance provided on the initial website was reversed. The initial website was based on the premise that the current funerary services industry was corrupt, opaque, and not oriented towards the customer. Love Convergence planned to supply detailed information about the ritual process to maximize customer choice and transparency of pricing, while minimizing the chances of salespeople to profit by selling overpriced funerals. But the company soon discovered that it was not practical to list explicit prices. Likewise eliminated was the detailed menu for funerary services, as this had simply raised more questions than it answered for the customers who called in. The opacity of the industry no longer seemed to be an issue. In reaction to customer behavior, the managers decided to reformat the website; at the same time, the product itself evolved. The option for customers to take a 3 percent annual return on the prepaid price recalls Cheris Chan's findings: insurance in 
China is best marketed as a type of investment rather than a form of protection. The filial imagery on the website appealed both to anxieties common in modernizing countries with Confucian heritage and to government concerns about the neglect of the elderly. In addition to fitting China's economic, political, and cultural contexts, the filial imagery on the website contributed to the ideological work of making the provision of a good funeral a sacred form of familial duty.

The methods that Love Convergence used when dealing with the businesses that actually provide funerary services also evolved rapidly. Tom Baker (1994) points out how insurance companies often use different visions of insurance when processing claims than they do when selling insurance policies (see also Heimer 2002; Stone 2002). When processing claims, the emphasis is placed on preventing insurance fraud, rather than providing for loved ones. Likewise, Love Convergence expressed a different vision of insurance to these businesses than it did on its website. In 2015, I attended some meetings at which the company pitched their business model to invited groups of funerary services providers. Their presentations suggested that the technology of a highly developed web-based platform, combined with the reputation of a well-established, well-resourced life insurance company, would revolutionize the industry. Customers would trust the reputation of an insurance company worth billions that had repeatedly paid out claims in the past; moreover, customers would be drawn to their expertly designed website. Consequently, people around the country would start prepaying their funerals with Love Convergence. Companies that actually provided funerary services (one-stop dragons) would have no choice other than to work with Love Convergence if they wanted to stay in business. Love Convergence also suggested that even though the companies might have to accept less money for their services than they had in the past, they would gain the security of having business lined up for funerals many years into the future. While the service providers who attended this meeting were polite, several follow-up interviews suggested that none of them signed a contract with Love Convergence. In 2016, Love Convergence managers told me that they no longer had any need for such contracts. There would always be funerary service providers and Love Convergence would simply line up the necessary services for its customers when the time arrived. Their experience in arranging funerals would allow them to know which providers gave good service at a reasonable price.

This change reverberated throughout their business model. Rather than contracts that bound service providers to conduct funerals at relatively low prices, Love Convergence hedged against inflation by charging 20 percent more than existing price levels. Their business visions changed even more radically. In 2015 the enthusiastic new recruit imagined a future company that would dominate funerary services as Uber dominates the taxi business. The web platform was the key to channeling customer demand through them and reducing other actors in the industry to accepting terms that Love Convergence dictated. This vision of 
their business was most likely pitched to investors, shareholders, and higher-level executives in Longevity Life, as well as the new employees. In practice, the web platform was not so successful and the business only attracted a certain niche market. Consequently, the managerial vision of the company shifted from one in which it dominated all other players in the industry to one in which it could easily work with the other players because there were many of them who competed against one another.

\section{Adopting and Adapting Business Visions from Elsewhere}

Love Convergence did not develop its insurance vision in a vacuum. Executives in Longevity Life constantly studied, visited, and held negotiations with other large companies, both overseas and in China. The establishment of Love Convergence involved three inter-related trends in contemporary capitalism and the funerary industry in particular. The first is the attempt to use internet technologies to "disrupt" existing sectors. The second is the consolidation of the funerary industry by large firms that see the potential for profit in death. The third is the search for new sources of profit by large financial and insurance businesses which often leads to new ways of defining what basic financial products such as insurance actually are.

Other attempts in China have been made to revolutionize the funerary business by establishing a web platform. A smaller-scale, more local attempt was made by the company Bi An in Beijing.? The claims Bi An made in relation to the existing industry in China closely resembled those made by Love Convergence (Kaiman 2015): they argued that other primary service providers were either seedy smallscale entrepreneurs or bureaucratic non-customer focused state-run businesses, neither of which provided transparent pricing or good service. On the surface there is a bit of truth in these claims. The stigmatization of funerary workers in China makes advertising difficult and causes funerary sector workers to be reluctant to discuss their work. Consequently, many people do not know where to go when they need to arrange a funeral. Moreover, for differing reasons, both small-scale entrepreneurs and state-run funeral home/crematoriums overprice some items to make up for the aspects of the service which are priced well under cost. But I would not go so far as accuse businesses of seediness because of these situations.

Bi An has been more successful in providing transparent pricing than Love Convergence. It does list explicit prices for many of its services on its website, perhaps because it only provides services in one city. But there are limits to this transparency and its ability to revolutionize or disrupt the industry. Even though many customers are happy with standardized packages, funerals can be highly individualized events, and Bi An, like all other companies in this industry, suggests contacting the company for an in-person consultation to determine the exact needs and price of a funeral in a specific instance. Second, like Love Convergence, Bi An does not advertise prices that are noticeably lower than other providers. 
Finally, all players in the funerary industry seem to agree that a web-based presence is important for the business. For an industry in which stigma can make traditional forms of advertising problematic, a web presence allows potential customers to search for information. But the usefulness of web advertising to the funerary industry does not necessarily make web platforms disruptive to the existing industry. Hundreds of one-stop dragon entrepreneurs and state-owned funerary parlors are all establishing web platforms.

In its original business vision, Love Convergence borrowed some of Bi An's rhetoric about the shortcomings of the funerary services industry, adding the language of sector-wide, nation-wide dominance and industry disruption. Since Longevity Life already was a huge company, with national coverage, ample capital to invest, and a reputation as an insurance company too big and safe to fail, it hoped to scale up Bi An's intentions in a revolutionary way.

The vision of how the scaling up of Bi An's rhetoric might work also drew from the experience of large companies in other countries that were consolidating the funerary industry. In the United States, for example, Service Corporation International (SCI) has been buying up small family-run funeral homes for decades and is now said to control over two thousand funeral homes (Barrett 2013). As Love Convergence is attempting to do, SCI offers standardized funeral service packages, which are advertised and depicted on websites, which can be prepaid, and which can even be carried out at any of the firm's funeral homes across the country should a family move or an individual die away from home. But also like Love Convergence, SCI has raised rather than lowered prices.

Unlike SCI, Love Convergence does not itself provide funerary services. It instead takes money from customers, invests it in its other businesses, and guarantees that it will find a reputable business to provide the services when the time arrives. Here it seems that Love Convergence did borrow from the model of Uber. It channels customers to independent contractors rather than providing service. One factor in Love Convergence's failure to disrupt and consolidate the industry may be the different financial environments in China and the United States. In the latter, there are estate planning benefits that encourage the prepaying of funerals. By prepaying a funeral, elderly people can spend down their assets in a way that makes them eligible for state benefits (places in nursing homes, for example). If heirs simply paid for the funeral out of the money they inherited, the net position would not be as advantageous. The existence of a financial environment which favors prepaying funerals in turn encourages the growth of large-scale funerary companies, who are in a better position to guarantee the provision of services many years into the future and in many locations across a given country. In China, at present, there are no financial advantages to prepaying a funeral.

Why does Love Convergence call their product a form of insurance? While there are forms of funeral insurance in the United States, such insurance is different to prepaying a funeral. My point is not to criticize a Chinese firm for 
using financial terms differently than they are used elsewhere. Rather, I wish to point out that the meaning of these terms is quite flexible, that it depends on the evolving legal, tax, and financial environments in which the terms are used, and that large companies often actively seek to stretch the meanings of such terms in their search for new products and modes of profit. In American financial terms, Love Convergence's product is halfway between a pre-paid funeral and a straightforward investment like a certificate of deposit. As Spencer Kimball (cited in Baker and Simon 2002a, 7), a leading American insurance law scholar puts it, "there is no good definition of 'insurance' for any purpose." As Baker and Simon (2002b, 27) argue, "insurance is not a unified institution."

\section{CONCLUSION}

As China's urban economy grows, as more and more goods and services are purchased from businesses staffed by strangers rather than provided by family members, work-units, or thrifty households, and as inequality grows and housing becomes more unaffordable, several trends in the economic transactions surrounding funerals emerge. Communities shrink, but the maintenance of social relations among related households remains important. Families may be careful about who they allow to enter their relatively private circles, but strive to keep some sort of familial network alive. Inheritance battles proliferate in part because of rapidly changing demographic patterns, but also because of the price of housing in relation to average incomes. As the population of those who are passing away comes to be dominated by the parents of only children, inheritance battles will wane, but the relative importance of the economics of inheritance is likely to remain high as long as apartments cost so much in relation to salaries. Though the importance of work units in the lives of urban people diminishes, the economies of government-dispensed benefits has not become less important. While China may attempt to privatize the businesses of providing health insurance and pensions, government regulation of these sectors will remain important. As long as the Chinese Communist Party is governing the country in an authoritarian fashion, it will want to use its association with these sectors to promote political loyalty.

The future of small- and large-scale businesses in China is harder to predict. The retreat of work units in the urban sector, coupled with the opening of migration from rural to urban areas, created the conditions for an explosion of smallscale entrepreneurship, as the one-stop dragon sector illustrates. However, as the economy continues to grow, as many urban business sectors become dominated by established players, and as emerging digital economies offer opportunities to a few large-scale players in a winner-take-all fashion, the space for small-scale business in large Chinese cities may shrink. Love Convergence attempted to squeeze space and profits out of the market currently dominated by one-stop dragon entrepreneurs. At least for the moment, this attempt appears to have failed, but 
that does not mean that future attempts will also fail. In addition to whatever other advantages they may hold, in China, large-scale businesses often have state backing, and this political capital could be the straw that tips the tide towards large-scale success.

Finally, note how the rhetoric of Love Convergence demonized the existing players in the funerary sector. Such rhetoric echoes, and takes advantage of, the stigmatization of rural-urban migrants working in the sector. It insinuates that they lack moral "quality", so of course they rip people off. While it is true that entrepreneurs like Mr. Chen make a reasonable living, it is also true that they work hard to provide an important service during a time when their clients have great need. I never heard rhetoric claiming that the wedding-banquet sector or the automobile sector, for example, was full of cheats, even though these businesses are also quite profitable. And of course not all one-stop dragon entrepreneurs are as successful as Mr. Chen. When companies like Love Convergence move into the funerary sector, prices for customers do not drop. They simply turn popular rhetoric about stigmatized populations to their own advantage. 